\title{
TINJAUAN KEMAMPUAN MENGGAMBAR MENGGUNAKAN POLA PADA ANAK DI TK B RA AL-FAZWA DELI SERDANG
}

\author{
Fitri Puspita Sari ${ }^{1 *}$, Azmi2 ${ }^{*}$, Raden Burhan SND ${ }^{3 *}$ \\ Program Studi Pendidikan Seni Rupa Jurusan Seni Rupa Fakultas Bahasa dan Seni \\ Universitas Negeri Medan \\ Jl. Willem Iskandar Pasar V Medan Estate, Kec, Percut Sei Tuan, Kab. Deli Serdang, Kode Pos 20371 \\ Sumatera Utara. Indonesia \\ Email: fitripuspita584@gmail.com
}

\begin{abstract}
Abstrak
Penelitian ini bertujuan untuk meninjau dan mengetahui kemampuan dan hasil karya anak dalam menggambar menggunakan pola di TK Al-Fazwa Deli Serdang. Metode penelitian yang digunakan yaitu metode penelitian Deskriptif Kualitatif. Populasi yang terdapat dalam penelitian ini sebanyak 3 karya hasil menggambar anak menggunakan pola. Sampel yang digunakan terdiri dari jumlah anak dalam kelas yaitu dengan menggunakan teknik total sampling yaitu teknik penentuan sampel yang menggunakan keseluruhan karya anak dalam kelas. Guna memperoleh data tinjauan tentang menggambar menggunakan pola di TK Al-Fazwa Deli Serdang. Setelah melakukan tinjauan langsung dan melakukan penelitian kepada anak-anak TK Al-Fazwa mendapatkan hasil karya dengan rata-rata nilai 78,00 dalam kateg ori penilaian karya B (Baik). Penilaian hasil karya pada objek fantasi hewan purbakala pada umumnya anak-anak dapat mengikuti teknik dan aturan dalam menggambar menggunakan pola dengan hasil akhir yang baik dalam indikator penilaian kerapian garis, perkembangan kognitif dan ketetapan garis dalam menggambar menggunakan pola.
\end{abstract}

Kata Kunci: tinjauan, kemampuan, menggambar pola.

\begin{abstract}
This research intend to review know the abilyty of children Deli Serdang using pattem. TK Al-Fazwa Deli Serdang method research used is Descriptive Qualitative population contained in this research as many as 4 result of the work drawing children using pattern. The sample to use consist the number of children, in one class that using the technic of total sampling that is technic sample. Using the every work of the child in the class. Order to obtain data, review about drawing using the patterns. TK Al Fazwa, get the result of the work in the average 78,00 in category assesment work B (Good). Assesment of the result the work on objeck fantasy Ancient animals purbakala in general, children canfollow the technic and arragement in drawing (picture) using patterns. With result in the and indicator assasment,neatness line expansion cognitive and decision line in drawing get pattern.
\end{abstract}

Keywords: review, ability, draw pattern

\section{PENDAHULUAN}

Taman kanak-kanak adalah jenjang pendidikan sebelum pendidikan dasar (SD). Pendidikan dasar merupakan suatu upaya pembinaan yang ditujukan bagi anak sejak lahir sampai dengan usia 6 tahun. Upaya pembinaan pendidikan dasar pada anak yang dilakukan melalui pemberian rangsangan pendidikan untuk membantu pertumbuhan dan perkembangan jasmani dan rohani anak.

Soesatyo (dalam Pamadhi,Sukardi dan Muis, 2008: 2.12) menjelaskan bahwa "Anak menggambar adalah menceritakan, mengungkapkan (mengekspresikan) suatu yang ada pada dirinya secara inten sif dan spontan dalam media gambar, maka karya lukis anak-anak adalah seni meskipun tidak dis amakan dengan karya lukis orang dewasa, namun syarat-syarat kesenian lukis an telah terpenuhi dengan adanya teknik artistik dan ekspresi."

Menggambar menggunakan pola pada tingkat TK untuk membantu mereka meningkatkan pola pikir, fokus dan berani menyelesaikan suatu gambar yang belum sempurna seperti ke satu titik yang lainnya sehingga tercipta satu buah gambar utuh. Menggambar dengan titik-titik adalah unsur dasar seni rupa yang paling kecil. Semua wujud sebuah karya, awalnya dihasilkan dari unsur titik-titik. Selanjutnya titik juga bis a menjadi pus at perhatian tersendirijika berkumpul 


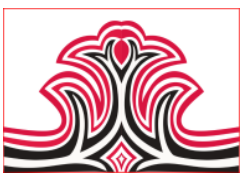

atau membentuk sebuah gambar namun belum sempurna.

Untuk lebih menyempurnakan pola titik-titk tersebut maka harus diikuti oleh pemanfaatan garis dalam sebuah sketsa digunakan untuk mencapai kesan tertentu seperti halnya dalam membuat sebuah karya gambar, kuat namun tetap terlihat sederhana. Sehingga akan menghasilkan bentuk visual (bahasa rupa).

Terkait dengan penjelasan di atas maka penelitian inidi RA AL-Fazwa, dan di TKIRA dimanapun mereka menggunakan kurikulum 2013. Alasan memilih TK AL-Fazwa adalah karena sekolah tersebut sudah menerapkan kurikulum 2013 dengan konsisten. Sehingga penulis ingin mengetahui lebih jauh bagaimana sebenarnya kegiatan mengg ambar dengan menggunakan pola. Pada umumnya anak didik yang berada di TK AL-Fazwa sangat antusias (berminat besar melaksanakan salah satu kegiatan dengan menggunakan pola.

Sejalan dengan perkembangan senirupa anak di RA AL-Fazwa sudah menghasilkan beberapa anak berpres tasi dalamlomba antara lain memenangi lomba. Begitu pula para pengajarnya sangat berkopeten membimbing untuk membentuk karakteristik sekaligus membantu pertumbuhan jasmani dan rohani agar anak memiliki kesiapan untuk memasukijenjang pendidikan yang lebih tinggi.

\section{KAJIAN TEORI}

\section{Pengertian Tinjauan}

Tinjauan adalah melihat, memeriks a secara langsung kemudian menarik kesimpulan. Kemudian tinjauan adalah hasil dari kegiatan meninjau, pandangan, pendapat (sesudah menyelidiki atau mempelajari) laporan tinjau an adalah tulis an yang berisi karya ilmiah dalam kurun waktu tertentu.

Tugas akhir biasanya berupa hasil penelitian dari bidang tertentu yang kemudian diujikan secara lis an untuk memperoleh nilai kelulusan.

Menurut kamus besar bahasa indonesia (KBBI) (2002:762) yang memiliki arti sebagai melihat,mempelajari dengan cermat, memeriksa dan menduga.

\section{Pengertian Menggambar}

Menggambar adalah kegiatan yang membentuk imajinasi, dengan menggunakan banyak pilihan dalam teknik dan alat. Kegiatan menggambar ini dilakukan dengan cara mencoret, menggores, menorehkan alat atau benda ke benda lain dan memberi warna, sehingga
Gorga : Jurnal Seni Rupa

Volume 09 Nomor 01 Januari-Juni 2020

p-ISSN: 2301-5942 | e-ISSN: 2580-2380

menimbulkan gambar. Menggambar merupakan suatu aktivitas memindahkan bentuk objek ke atas bidang dua dimensional dengan cara menggoreskan y ang dapat meninggalkan kesan atau bekas (Nainggolan, 2018: 214). Aktivitas menggambar initidak lepas dengan apa yang disebut dengan minat atau kemauan, dimana minat tersebut tidak dapat dipaksakan untuk menggambar sesuatu yang diinginkan oleh orang lain, hal ini harus memang natural datang dari dalam diri sendiri "minat merupakan keinginan yang timbul dan dalam diri (internal) seseorang akan ketertarikan terhadap sesuatu yang interest berasal dari lusr diri (eksternal), menimbulkan keinginan untuk mendekati, mempelajari, menyentuh, dan lain sebagainya untuk lebih dekat lagi” (Kartono, 2020: 129-120).

Salah satu cara anak-anakberkomunikasi kepada orang lain yaitu dengan cara menggambar. Apalagi, ketika gambar tersebut ditanggapi oleh orang tua dengan pertanyaan tentang makna dan arti bentuk gambar yang dihasilkan. Sifat kepribadian anak pada awalnya adalah masih bersatunya antara alam pikiran dan perasaan anak. Menggambar merupakan salah satu media untuk berkomunikasi dengan orang lain. Pamadhi, Sukardi, dkk (2017:2.9) berpendapat bahwa manfaat menggambar bagi anak adalah sebagai berikut: Alat untuk mengutarakan (berekspresi) isi hati, pendapat maupun gagasan. Media bermain fantasi, imajinasi dan sekaligus sublimasi. Stimulasi bentuk ketika lupa, atau untuk menumbuhkan gagasan baru. Alat menjelaskan bentuk atau situasi. Misalnya, anak-anak sering mengambarkan keadaan ibu memasak di dapur yang ditemani seekor kucing, semua ini merupakan komunikasi dan intrapersonal (ada dalam bayangan anak).

Pada umumnya pengertian menggambar adalah membuat gambar, kegiatan ini dilakukan dengan cara mencoret, menggores, menorehkan benda tajam ke benda lain dan memberi warna, sehingga menciptakan sebuah karya gambar.

Menggambar merupakan kebiasaan anak-anak, kegiatan menggambar seperti halnya menyanyi dapat dilakukan dengan kesadaran penuh, berupa maksud dan tujuan tertentu maupun sekedar membu at g ambar tanpa arti. Kegiatan ini dimulai deng an menggerakkan tangan untuk mewujudkan suatu bentuk gambar secara tidak disengaja, apalagi ketika anak tersebut ditanggapi oleh orang tua dengan pertanyaan tentang makna dan arti bentuk gambar yang dihasilkan. 


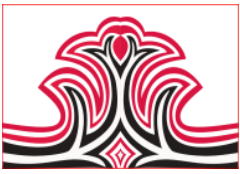

3.Menggambar Menggunakan Pola pada Anak Dalam menggambar pola ada beberapa ahli berpendapat yaitu, Suryawati, Radiona, dkk (2011:2) berpendapat bahwa "pola dasar adalah bentuk awal dalam menggambar yang belum di ubah".

Menggambar menggunakan pola pada anak TK dilakukan untuk melatih cara berpikir sekaligus membimbing mereka untuk menciptakan satu buah karya gambar dengan mengabungkan titik-titik.

Sedangkan titik sendiri adalah salah satu unsur seni rupa yang paling sederhana yang terkecil dan tersusun sehingga menghasilkan sebuah karya seni. Tahap ini berlaku bagi anak berusia 5 sampai dengan 6 tahun (kurang lebih usia pendidikan sekolah taman kanakkanak).

Robins (2004:3) dalam belajar melukis abstrak mengemukakan bahwa "tidak perlu membuat lukisan realis (Nyata) jika memang tidak menginginkannya, banyak pelukis terkenal melukis pola-pola biasa dengan warna-warna cerah dengan bentuk-bentuk menarik dan unik".

Dilanjut dengan Dwijawiyata (1998:1) dalam Pola Bentuk Dan Warna Untuk TK mengemukakan bahwa "pola gambar bentuk dan warna ini merupakan acuan utama untuk anak-anak TK (Taman Kanak-Kanak) yang disusun dengan garis-garis besar program kegiatan pembelajaran di taman kanak-kanak tahun 1994 buku meng gambar dengan pola bentuk dan wama ini disusun guna membantu anak-anak mengembangkan kemampuan berbahasa, daya pikir, daya cipta, dan keterampilan".

Dalam menggambar menggunakan pola dibawah ini ada beberapa objek sederhana tentang hewan fantasi sebagai bentuk dasar menggambar dengan menggunakan pola antara lain sebagai berikut:

Gambar anak-anak dapat dikelompokkan berdasarkan periodisasi. Pengelompokkan periodisasi karya seni rupa anak (gambar) bertujuan untuk mengenali karakteris tik perkembangan gambar anak berdasarkan usia. Periodis asi perkembangan gambar anak banyak dikemukakan oleh para ahli seni. Menurut Lowenfeld (1958:86-216) tahap perkembangan senirupa anak ada lima namun yang digunakan dalampenelitian ini hanya tiga tahapan saja, yaitu sebagai berikut :
Gorga : Jurnal Seni Rupa

Volume 09 Nomor 01 Januari-Juni 2020

p-ISSN: 2301-5942 | e-ISSN: 2580-2380

\section{1). Mamenchisaurus}

Hew an tersebut tekenal karena memliki leher yang sangat panjang, yang mencapai setengah panjang tubuh keseluruhannya memiliki panjang tubuh mencapai 35 meter ini ialah salah satu hew an yang akan saya jadikan salah satu bahan yang diperaktekkan.

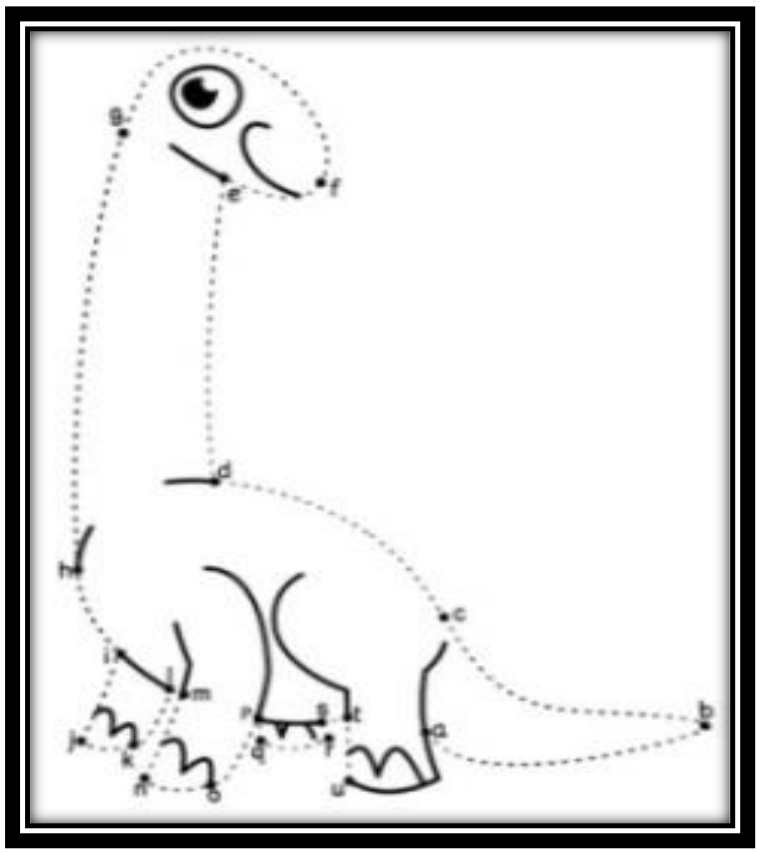

Gambar 1. Super Seru Menggambar an Mewrnai Dinosaurus (Sumber: Banbang, 2018: 3)

\section{2). Stegosaurus}

Hewan tersebut terkenal dengan sebutan kadal beratap karena sisik besar di punggugnya, spesies ini adalah salah satu jenis Dinosaurus yang paling muda diidentifikasi, karena kedua baris sisik yang saling silang dipunggungnya.

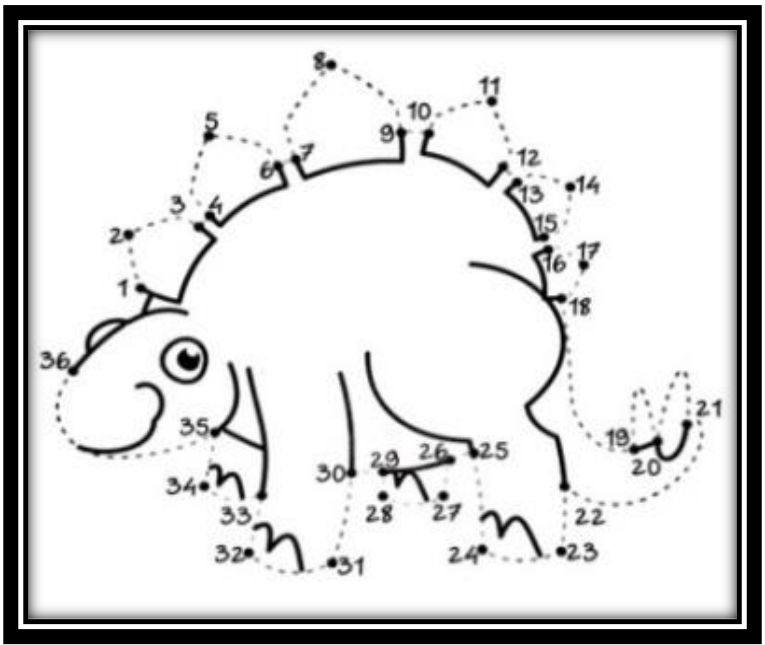

Gambar 2. Super Seru Menggambar an Mewrnai Dinosaurus (Sumber: Banbang, 2018: 5) 


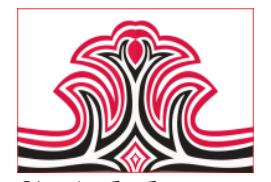

\section{3). Ankylosaurus}

Hewan ini termasuk hewan purbakala yang memiliki tubuh sepanjang 9 meter dan beratnya mencapai setidaknya 7 ton, hewan ini memiliki tubuh yang dilindungi oleh cangkang keras ditubuhnya.

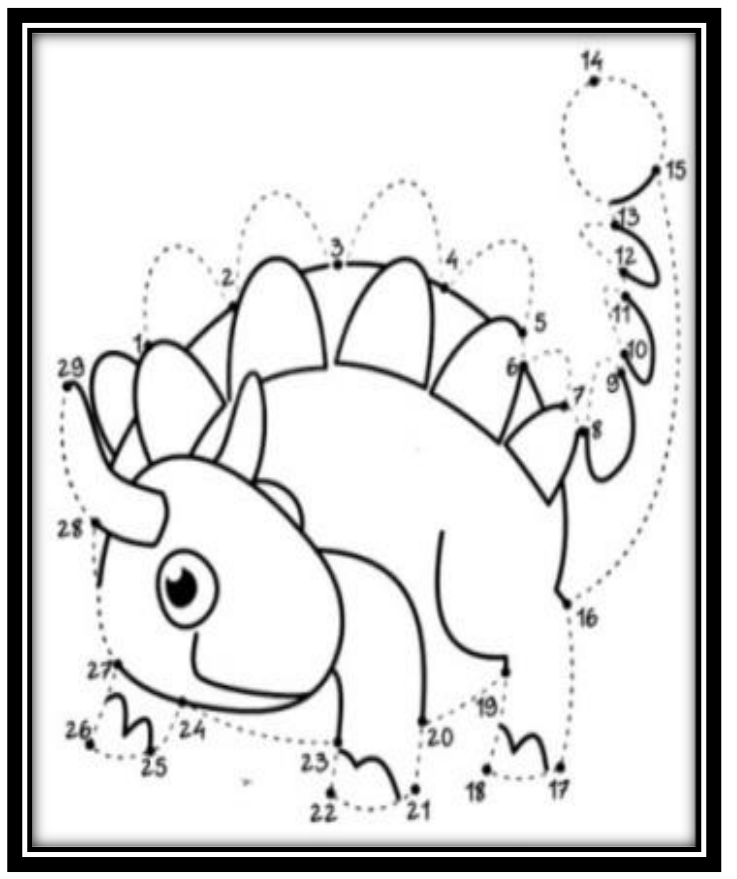

Gambar 3. Super Seru Menggambar an Mewrnai Dinosaurus (Sumber: Banbang, 2018: 7)

\section{METODE PENELITIAN}

Dalam penelitian ini saya menggunakan metode Kualitatif yang berbentuk deskriptif, berupa kata-kata lisan atau tulis an tentang tingkah laku dilapangan yang dapat diamati (Taylor dn Bogdan, 1984) dalam buku Metode Penelitian (2018:329). Data kualitatif dapat dipilih menjadi 3 jenis (Patton, 1990) dalam buku Metode Penelitian sebagai berikut: Hasil pengamatan, uraian rincian tentang situasi, kejadian, interaksi, dan tingkah laku yang diamati di lapangan. Hasil pembicaraan, kutipan langsung dari pernyataan orangorang tentang pengalaman,sikap,keyakinan,dan pemikiran mereka dalam kesempatan mewawancara mendalam. Bahan tertulis, petikan atau keseluruhan dokumen, surat-menyurat, rekaman, dan kasus-kasus sejarah.

Data kualitatif ini berwujud uraian, terperinci, kutipan langsung, dan dokumentasi khusus. Menurut pengalaman dan interaksi s osial dari subjek penelitian sendiri. Dalam penelitian kualitatif, akan terjadi tiga kemungkinan terhadap "masalah" yang dibawah peneliti dalam penelitiannya. Deskriptif adalah suatu rumusan masalah yang memandu peneliti untuk
Gorga : Jurnal Seni Rupa

Volume 09 Nomor 01 Januari-Juni 2020

p-ISSN: 2301-5942 | e-ISSN: 2580-2380

mengeks plorasi dan atau memotret situasi sosial yang akan di teliti secara menyeluruh, luas dan mendalam.

\section{HASIL DAN PEMBAHASAN}

1.Hasil

1).Karya 1

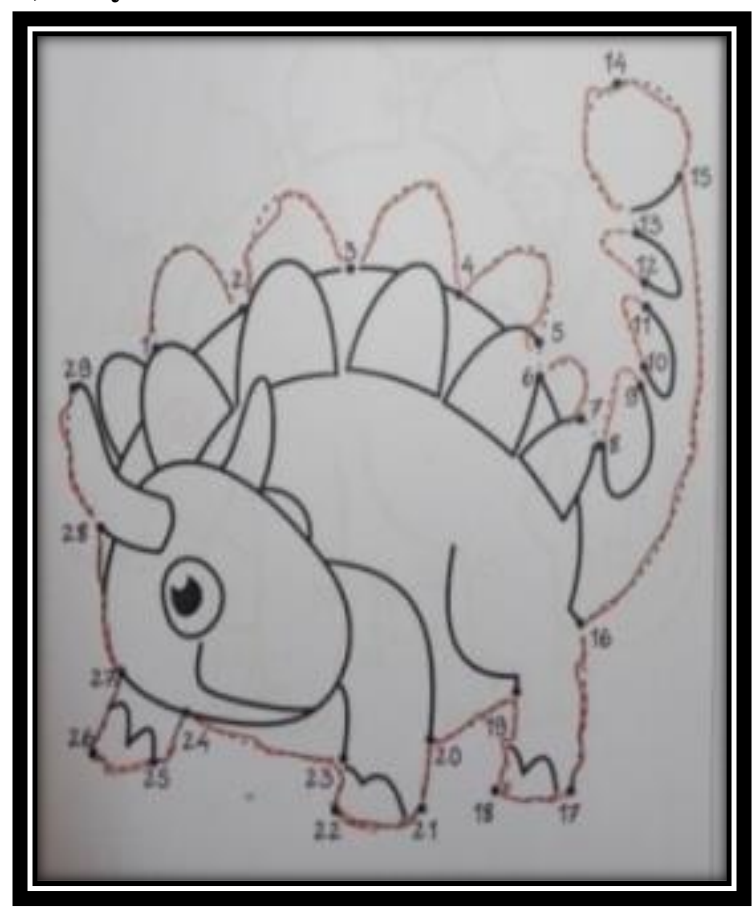

Gambar 4. Karya Fadhi

(Sumber: Fitri Puspita Sari, 2019)

Berdasarkan hasil penelitian indikator ketepatan garis pada karya 1 memiliki ketepatan dalammeng garis yang dapat mewakili bentuk asli serta kesesuaian dalam bidang gambar tidak terlalu kecil. Pada indikator Bentukgambar tersebut memiliki bentuk karakter yang mudah dikenali, dikarenakan bentuk dapat terlihat dari gabungan dari beberapa garis bersambung. Pada indikator kerapian garis, karya memiliki kemampuan dalam menarik garis dan dapat menyempurnahkan gambar dengan tarikan garis yang spontan. 


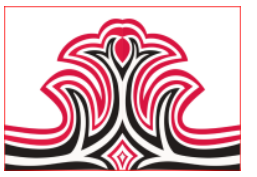

2).Karya 2

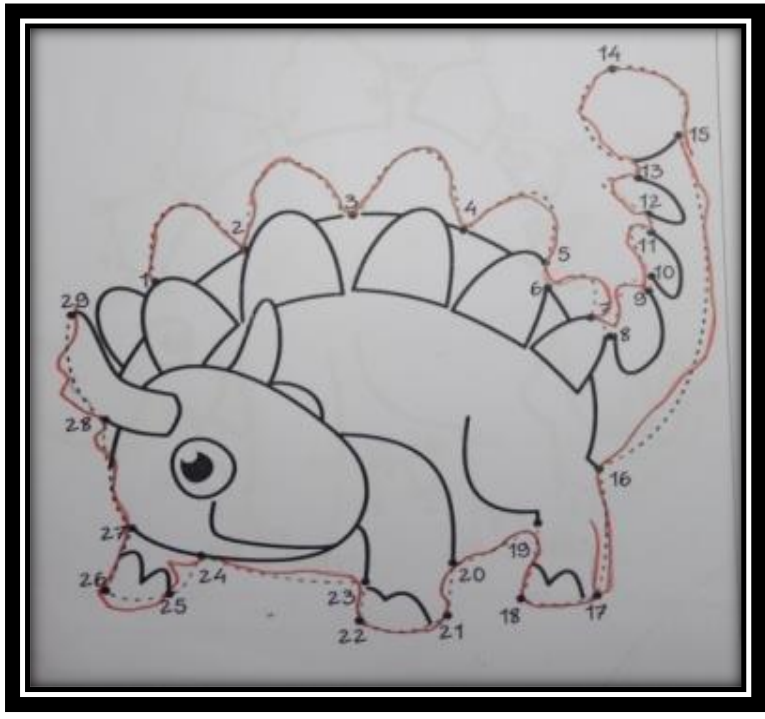

Gambar 5. Karya Abizar

(Sumber: Fitri Puspita Sari, 2019)

Berdasarkan hasil penelitian indikator ketepatan garis pada karya 2 memiliki ketepatan dalammeng garis yang hampir dapat mewakili bentuk asli serta kesesuaian dalam bidang gambar. Pada indikator perkembangan kognitif gambar tersebut memiliki bentuk karakter yang sedikit mudah dikenali, dikarenakan bentuk dapat terlihat dari g abung an daribeberapag aris bersambung.

pada indikator kerapian garis kurang dalam kategori sempurnah dikarenakan banyak garis yang masik dilakukan secara berulang-ulang dan tidak sesuai sketsa gambar yang ditentukan.

\section{3).Karya 3}

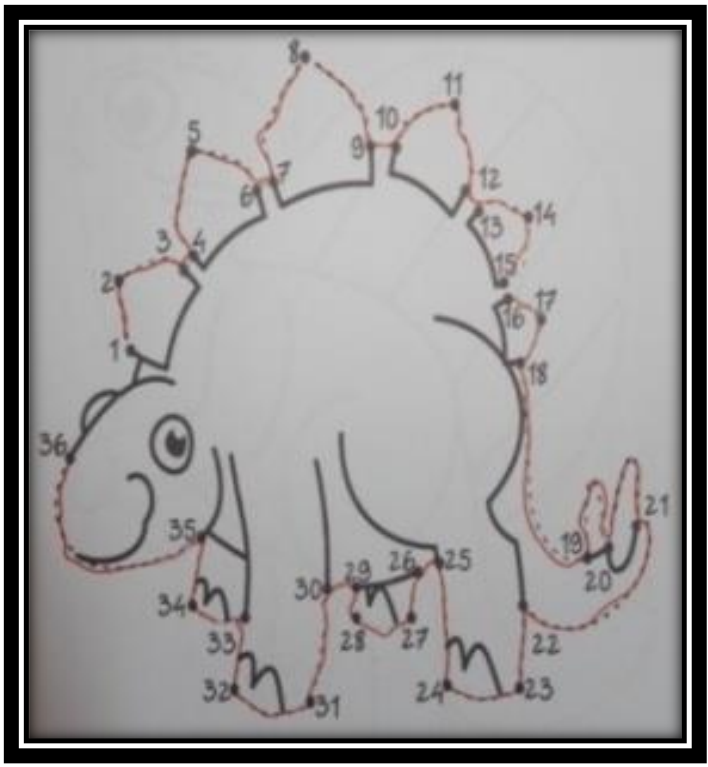

Gambar 6. Karya Habi

(Sumber: Fitri Puspita Sari, 2019)
Gorga : Jurnal Seni Rupa

Volume 09 Nomor 01 Januari-Juni 2020

p-ISSN: 2301-5942 | e-ISSN: 2580-2380

Berdasarkan hasil penelitian indikator ketepatan garis pada karya 3 memiliki ketepatan dalammeng garis yang hampir dapat mewakili bentuk asli serta kesesuaian dalam bidang gambar. Pada indikator perkembangan kognitif gambar tersebut memiliki bentuk karakter yang sedikit mudah dikenali, dikarenakan bentuk dapat terlihat dari gabung an dari beberapa garis bersambung.

\section{Pembahasan}

Berdasarkan data-data yang telah dideskripsikan, dianalisiskan maka diperoleh bahwa karya gambar menggunakan pola pada karya 5 dalam penerapan ketepatan garis, bentuk, dan kerapian garis di kategorikan Sangat Baik deng an jumlah nilai rata-rata $\mathbf{8 0 , 3 3}$. Berdasarkan data-data yang telah dideskripsikan, dianalisiskan maka diperoleh bahwa karya gambar meng gunakan pola pada karya 13 dalam penerapan ketepatan garis, bentuk, dan kerapian garis di kategorikan Sangat Baik dengan jumlah nilai ratarata $\mathbf{8 5 , 2 2 2}$. Berdasarkan data-data yang telah dideskripsikan, dianalisiskan maka diperoleh bahwa karya gambar menggunakan pola pada karya 21 dalam penerapan ketepatan garis, bentuk, dan kerapian garis di kategorikan Sangat Baik dengan jumlah nilairatarata 86,10 .

\section{KESIMPULAN DAN SARAN}

\section{Kesimpulan}

Berdas arkan penelitian yang telah dilakukan maka hasil menggambar menggunakan pola pada anak B di TK AlFazwa Deli Serdang dapat ditarik kesimpulan yaitu hasil karya anak pada ke tiga karya tersebut menjelaskan bahwa anak-anak TK Al-Fazwa Deli Serdang dapat menyelesaikan karya menggambar mengunakan pola dengan baik, walau pun ada beberapa tarikan garis yang tidak pada sketsa yang telah di tentukan namun anak-anak mampu menarik tarikan garis sesuai dengan urutan abjad dan angka yang baik.

\section{Saran}

Berdasarkan hasil penelitian, analisisi dan kesimpulan penelitian, maka peneliti menyarankan kepada guru yaitu: Dalam proses pembelajaran ada baiknya guru lebih berani memberikan topik pembelajaran yang sesuai dengan standart pembelajaran kurikulum TK yang terbaru, sehingga anak dapat memahami pembelajaran yang baik.

Sebelummemulaipembelajaran baru, adabaiknyaguru mengulas kembali pembelajaran sebelumnya, agar anak tetap ingat dan dapat mengulang pembelajaran sebelumnya dikala mereka sendiri. 
Harapan peneliti untuk kedepannya pendidikan anak lebih di utamakan dan diperhatikan, karna taman kanak-kanak (TK) adalah tempat awaldalammengenal dunia pendidikan dan tempat untuk menunjukkan karakter anak secara bebas dalamberinteraksi temadap orang lain, dan guru sebagai orang tua sudah sewajarnya memberikan perhatian serta sebagai pendamping pengganti,fasilitator dan mendidik anak sesuai fitrah.

\section{DAFTAR RUJUKAN}

Bambang. (2018). Super Seru Menggambar Mewarnai Dinosaurus. Yogyakarta: Kata Buku

Dwijawijaya. (1998). Pola Bentuk da Wama Yogyakarta:

Kartono, G., Mesra, M., \& Azis, A. C. K. (2020) Pengembangan Media Ajar Grafis Komputer Materi WPAP dalam Bentuk E-book dan Video Tutorial Bagi Mahasiswa Seni Rupa. Gorga: Jurnal Seni Rupa, 9(1), 127132.

KBBI. (2014). Kamus Besar Bahasa Indonesia. Jakarta: Penerbit Gita

Lowenfeld, Victor. (1958). Creative And Mental Growth. America: The Macmiilan Company

Muliawan, Porrie. (1985). Kontruksi Pola Busana Wanita. Jakarta: PT.BPK Gunung Mulia.

Nainggolan, M., Silaban, B., \& Azis, A. C. K. (2018). Analisis Karya Gambar Bentuk Siswa Kelas VII SMP Negeri 1 Simangumban Berdasarkan Prinsip-Prinsip Seni Rupa. Gorga: Jurnal Seni Rupa, 7(2), 212-217.

Pamadhi, Hajar. dkk. (2017). Seni Keterampilan Anak. Tangerang Selatan: CV Risqi Utama Mandiri.

Robins, Deri. (2007). Belajar Melukis. Solo: Tiga Serangkai Pustaka Mandiri.

Suryawati, Radion. dkk. (2011). Membuat Pola. Jakarta: PT REMAJA ROSDAKARYA

Loita, Aini. (2017). Karakteris tik Pola Gambar Anak Usia Dini. Early Childhood. Jurnal Pendidikan, 01( 01), 01-14. 